\title{
The Combination of Laser Therapy and Metal Nanoparticles in Cancer Treatment Originated From Epithelial Tissues: A Literature Review
}

\author{
Reza Fekrazad ${ }^{1}$, Nafiseh Naghdi ${ }^{2}$, Hanieh Nokhbatolfoghahaei ${ }^{3}{ }^{*}$, Hossein Bagheri ${ }^{4}$ \\ ${ }^{1}$ Laser Research Center in Medical Sciences (LRCMS), Department of Periodontics, Faculty of Dentistry, AJA University of \\ Medical Sciences, Tehran, Iran \\ ${ }^{2}$ Laser Research Center of Dentistry, Tehran Research Institute, Tehran University of Medical Sciences, Tehran, Iran \\ ${ }^{3}$ School of Advanced Technologies in Medicine, Shahid Beheshti University of Medical Sciences, Tehran, Iran \\ ${ }^{4}$ Dental Materials Research Center and Department of Operative Dentistry, Faculty of Dentistry, Mashhad University of \\ Medical Sciences, Mashhad, Iran
}

\author{
*Correspondence to \\ Hanieh Nokhbatolfoghahaei, DDS; \\ PhD Student, School of Advanced \\ Technology in Medicine, Shahid \\ Beheshti University of Medical \\ Sciences, Tehran, Iran. \\ Tel: +989122905305; \\ Fax: +982188015800 \\ Email: h-nokhbeh@farabi.tums.ac.ir
}

Published online 27 March 2016

\begin{abstract}
Several methods have been employed for cancer treatment including surgery, chemotherapy and radiation therapy. Today, recent advances in medical science and development of new technologies, have led to the introduction of new methods such as hormone therapy, Photodynamic therapy (PDT), treatments using nanoparticles and eventually combinations of lasers and nanoparticles. The unique features of LASERs such as photo-thermal properties and the particular characteristics of nanoparticles, given their extremely small size, may provide an interesting combined therapeutic effect. The purpose of this study was to review the simultaneous application of lasers and metal nanoparticles for the treatment of cancers with epithelial origin. A comprehensive search in electronic sources including PubMed, Google Scholar and Science Direct was carried out between 2000 and 2013. Among the initial 400 articles, 250 articles applied nanoparticles and lasers in combination, in which more than 50 articles covered the treatment of cancer with epithelial origin. In the future, the combination of laser and nanoparticles may be used as a new or an alternative method for cancer therapy or diagnosis. Obviously, to exclude the effect of laser's wavelength and nanoparticle's properties more animal studies and clinical trials are required as a lack of perfect studies.
\end{abstract}

Keywords: Nanoparticles; Cancer, Therapy-related; Laser.

\section{Introduction}

LASER, despite its history, is recognized as a new technology worldwide. Also, nanotechnology is one of the most recent fields of science. These two technologies, with their specific characteristics, have played a major role in medicine and dentistry. Simultaneous use of these two technologies has created a new approach to modern medicine and dentistry, like diagnosis and treatment of cancer, drug releasing systems, rapid medical testing, tooth sensitivity treatment and improving the adhesion to tooth structure in dentistry.

Recent investigations showed that there has been an increase in the prevalence of cancers. According to GLOBACON (related to World Health Organization) there were about 12.7 million patients suffering from cancer worldwide in 2008 (excluding non-melanoma skin cancer) which is expected to reach 21 million by 2030 . This increase requires new treatment methods to be developed.

Cancers are classified based on different aspects such as classification according to the cell origin. Carcinoma includes cancers originating from epithelial cells (e.g., epithelial squamous cell cancer), or the cells that cover the internal organs (such as lung cancer) or glands (e.g. breast cancer). Sarcoma refers to cancer originating from mesenchymal tissues such as bone and muscle. Leukemia and lymphoma include cancers originating respectively from blood-forming and immune cells. ${ }^{1}$

Several methods have been used to treat cancers, including surgery, chemotherapy, radiation therapy, etc. Nowadays, with the recent advances in medical science and new technologies, novel methods have been introduced such as hormone therapy, photodynamic therapy (PDT), treatments using nanoparticles and eventually combinations of lasers and nanoparticles. PDT depends on the availability of oxygen in tumours, but in methods using lasers and nanoparticles, there is no such limitation and they can be used as alternative methods.

Nano technology refers to work at the atomic, molecular and supra-molecular levels (scale of 1-100 nm) in order to

Please cite this article as follows: Fekrazad R, Naghdi N, Nokhbatolfoghahaei $\mathrm{H}$, Bagheri $\mathrm{H}$. The combination of laser therapy and metal nanoparticles in cancer treatment originated from epithelial tissues: a literature review. J Lasers Med Sci. 2016;7(2):62-75. doi:10.15171/ jlms.2016.13. 
understand, create and make use of materials, structures, devices and systems with fundamentally new properties and functions due to their small structure. ${ }^{2}$

Nanomaterials are classified based on various parameters including material, size (dimension), shape, etc. with each of them have different applications. Today, nanoparticles (which are the nanomaterial with 3 dimensions) with unique characteristics and tunable optical properties provide valuable cell therapy methods. Great progress has been made in the use of metal nanoparticles for biomedical applications due to their unique size and shape properties. ${ }^{3-6}$ Among metallic nanoparticles, gold and silver nanoparticles are highly regarded with increased use in biomedical field. ${ }^{3,7,8}$

Nanoparticles are most widely used in the biomedical fields for diagnosis and treatment of cancer. Treatment of tumours surrounded by vital tissues is problematic and there is a probability that tumour margins remain unclear. On the other hand, cutting healthy tissues may lead to unacceptable beauty and medical results. Application of nanoparticles provides a high degree of accuracy. On the other side near infrared (NIR) radiation is an interesting energy source as human blood and body tissues have the minimum absorption in this wavelength, thus deeper tissues can be reached. ${ }^{9}$

The unique features of lasers such as photo-thermal properties and the extremely small size of nanoparticles (which creates new physical effects that are mainly a result of domination of the quantum properties in contrast to classical properties), provide an interesting combined therapeutic effect. Thermal therapy procures a fast recovery, shorter hospital stay, less complications and is easy to perform. ${ }^{10}$

There are a variety of nanoparticles, and each has its own unique properties and applications such as nanorings, nanoshells, nanorods, nanopores and nanowires, etc. Depending on the peak absorption of nanoparticles, different lasers are used. For example researchers have investigated NIR-tunable nanostructures (nanoshells, ${ }^{11-13}$ nanorods, ${ }^{14}$ and nanoclusters, ${ }^{13,15}$ etc) for photo-thermal functionality. ${ }^{16}$

In fact nanoparticles that have been synthesized to date, have the most absorption in the wavelength range of 600-1200 nm (laser diode). In the future, nanoparticles with maximum absorption in other wavelengths may be synthesized.

Liver, spleen and kidneys are sites that are most effected by nanoparticles. ${ }^{17}$ Morbidity and renal complication are the cause of use of gold nanoparticles modified with certain thiol monolayers such as tiopronin. ${ }^{18}$ Variable toxicity of nanoparticles is achieved through different size and the material which coats them. For example glutathione-coated gold nanoparticles have $100 \%$ survival rate even at concentrations up to and including $60 \mu \mathrm{M} .{ }^{18} \mathrm{In}$ vestigations show that nanoclusters with smaller size can effectively reduce their toxicity. ${ }^{17,19}$ The excretion of nanoparticle is through renal clearance. ${ }^{17}$

The aim of this study was the review of the literature in which lasers and nanoparticles were used simultaneously to treat cancers with epithelial origin.

\section{Results}

A thorough search in electronic sources Science Direct, PubMed, Google Scholar was performed for clinical articles between 2000 and 2013 with the following keywords "Au nanoparticle," "Ag nanoparticle," "Cancer therapy," "Laser," and "Combination of $\mathrm{Au} / \mathrm{Ag}$ in cancer therapy." Overall, 400 articles were found in relation to nanoparticles and lasers topics, among which 250 articles used nanoparticles and lasers in combination while in more than 50 articles nanoparticles and laser were used together in the treatment of cancer with epithelial origin. Most of these studies addressed breast cancer but could be extended to oral tumours.

After assessment of the articles, they have been categorized into different groups based on the type of nanoparticles used in combination with lasers.

\section{Studies on Gold Nanoparticles (Au) Use in Combination With Laser}

As mentioned above great progresses have been made in the use of metal nanoparticles especially gold. Because of their unique properties which depend on their size and shape, nanoparticles are used for medical purposes. Among different nanostructures gold nanoparticles are the most appropriate candidate in photothermal sensitizing for the following reasons: they powerfully absorb laser light, are nontoxic, easily conjugates with proteins and antibodies and have tunable optical properties. ${ }^{3}$

Different types of nanoparticles were used in various experiments which consisted of silica gold nanoshells, gold nanorods, gold nanocages, gold-gold sulfide nanoparticles and hollow gold nanoshells. These nanoparticles have good absorption in NIR spectra which provides the most transformation and the least reflection of light in vital tissues. Transformation of nanoparticles can be done in a systemic way (through intravenous injection)., ${ }^{9,10}$ Many studies have been done in this field.

\section{In Vitro Studies}

In 2012, Kuo et al evaluated dual-modality photodynamic therapy (PDT) and photothermal therapy (PTT) by gold nanomaterials conjugated with indocyanine green. Human lung carcinoma malignant cell line (A549) conjugated with $A b_{E G F R}-\mathrm{Au} \mathrm{NP}$ of different sizes were irradiated by $808-\mathrm{nm} \mathrm{CW}$ diode laser ([22.5 W/ $\left.\left.\mathrm{cm}^{2}\right],\left[20 \mathrm{~W} / \mathrm{cm}^{2}\right]\right)$ femtosecond and Ti:sapphire femtosecond laser $(700 \mathrm{~nm})$ at $2 \mathrm{~mW}$ for 10 minutes integration. PTT and PDT killed cancer cells in an efficient manner. ${ }^{20}$

Kessentini and Barchiesi compared quantitatively optimized nanorods, nanoshells and hollow nanospheres for PTT. Several study groups consisting of shallow cancer (e.g. skin cancer) and deep cancer conjugated with different types of nanoparticles: (1) nanorods: (a) spheroid (b) cylinder (c) capped cylinder, (2) nanoshells, and (3) hollow nanospheres (different sizes). The samples were 
exposed to pulsed laser (633 $\mathrm{nm}$ laser [shallow cancer] and $800 \mathrm{~nm}$ [deep cancer]). They found that the hollow nanospheres are more efficient for shallow cancer therapy; whereas hollow nanospheres and nanorods, present similar absorption efficiencies for deep cancer therapy. ${ }^{21}$ In 2011, Fekrazad et al investigated the use of anti-HER2 immuno-nanoshells in treatment of oral squamous cell carcinoma. HER2-positive KB cells and HER2-negative HeLaS3 were bound with gold-silica nanoshell conjugated with anti-her2 $(100 \mathrm{~nm})$ and then exposed to laser irradiation at $810 \mathrm{~nm}$ and $4 \mathrm{~W} / \mathrm{cm}^{2}$ for 2 minutes. Significant cell death in the KB tumour cell cultures was reported, while there was no evidence of cellular damage or death in the HeLaS3. ${ }^{22}$

Day et $\mathrm{al}^{23}$ investigated the diagnosis and treatment of cancer by antibody-conjugated gold-gold sulfide nanoparticles. SK-BR-3 breast carcinoma conjugated with ant ti-HER2 antibodies conjugated GGS-NPs was exposed to an $800 \mathrm{~nm}$ pulsed laser, consisting of low laser powers (1 $\mathrm{mW}$ ) for making image and high laser powers $(50 \mathrm{~mW})$ for inducing cancerous cells to death. Regarding this study, imaging and therapeutic capability of nanoparticles depended on the amount of laser power. ${ }^{23}$ Other studies in this area have been summarized in Table 1.

\section{Animal Studies}

Considering the positive results of several in vitro studies, researchers have continued their work on animal models. In 2012, Ma et al showed that Au capped magnetic core/ mesoporous silica shell nanoparticles have a synergistic influence of mixed chemo- and photo-thermo therapy. Human breast cancer MCF-7 cells which were seeded in 96-well plate were exposed to $808 \mathrm{~nm}$ high power multimode pump laser at a power density of $2.0 \mathrm{~W} / \mathrm{cm}^{2}$ with a beam diameter of $5 \mathrm{~mm}$ for 5 minutes. A synergistic effect in loosing viability of cancer cells was reported. They also evaluated this effect in an in vivo study. Walker 256 cells were implanted into SD mice and Au NRs were injected into the tumours under anaesthesia. Then the mice were irradiated by $808 \mathrm{~nm}$ high power multimode pump laser (beam diameter of $5 \mathrm{~mm}$ and power density of $2.0 \mathrm{~W} \mathrm{~cm}^{-2}$ ) for 5 minutes. They could lower the dosage of anti-cancer drug through the synergistic effect, so the toxicity of the drug was limited. ${ }^{25}$

In 2011, Xie et al showed that Integrin av $\beta 3$-targeted gold nanoshells increase tumour vasculature-specific imaging and therapy. HNSCC cell line SCC-4 were inoculated subcutaneously in nude rats for PET imaging for setting up an HNSCC xeno graft model. Then 64Cu-NS-RGD$\mathrm{fK}$ was injected into the rats' tail veins and PET imaging was done. For thermoablation analysis the subcutaneous colorectal cancer xeno graft was performed in nude mice, using HCT116 human tumour cells. Then, NS-PEG5K and NS-RGDfK solutions were injected via the tail vein (in each group 2 mice) and mice were exposed to $808 \mathrm{~nm}$ NIR laser light with a spot size of $1 \mathrm{~cm}$ and $1.2 \mathrm{~W} 75 \%$ duty cycle. Improvement of tumour targeting by conjugation of NSs to cyclo (RGDfK) was seen in all test groups.
However, more tumour necrosis was observed in subablative group. ${ }^{49}$ Similar studies are summarized in Table 2. Accordingly, it can be concluded that gold nanoparticles and lasers can be used in the treatment of cancer.

\section{Studies Using Silver Nanoparticles (Ag) in Combination With Laser}

Prominent for their antibacterial and wound healing behaviour, silver nanoparticles have lately made their way into cancer therapies. ${ }^{65}$ When tested on living cells, they were captivatingly shown to have dual activity, inhibiting the growth and the division of tumour cells and their nuclei, while being biocompatible for the healthy ones. ${ }^{66,67}$ Further recent results exemplify that silver nanoparticles with different sizes could enhance magnetic induced thermo-sensitivity of glioma cells depending on their size. ${ }^{68}$

\section{In Vitro Studies}

In 2011, Boca et al investigated chitosan-coated triangular silver nanoparticles as a novel set of biocompatible and very effective photo-thermal transducers for in vitro cancer cell treatment. In this study they reported the performance of newly synthesized chitosan-coated silver nano-triangles (Chit-AgNTs) with strong resonances in NIR to operate as photo-thermal agent against a line of human non-small lung cancer cells (NCI-H460). The results revealed a novel class of biocompatible plasmonic nanoparticles with high potential to be implemented as effective phototherapeutic agent in the battle against cancer. ${ }^{65}$ As these studies (Table 3) show, silver nanoparticles are effective in cancer therapy.

\section{Combination of $\mathrm{Au} / \mathrm{Ag}$}

Only two papers have discussed the application of laser with a combination of silver and gold nanoparticles, probably because of the similar advantages of both elements. In 2008, Huang et al investigated the effect of selective PTT on mixed cancer cells, using aptamer-conjugated nanorods. To reach this aim they designed an aptamer-based nanoparticle, which could treat targeted cancer cell selectively and efficiently. They also showed that in contrast with other nanomaterials such as gold nanorods or nanoshells which need high power of laser irradiation, this combination of $\mathrm{Au}-\mathrm{Ag}$ nanorods requires less laser irradiation to induce cell death in cancerous tissues. ${ }^{71}$

In 2008, Hu et al investigated core-free nano structured $\mathrm{Au}_{x} \mathrm{Ag}_{1-x}$ dendrites as a new therapeutic agent in treatment of cancer. Two types of $\mathrm{Au}_{0.3} \mathrm{Ag}_{0.7}$ and $\mathrm{Au}_{0.06} \mathrm{Ag}_{0.94}$ capped with anti-EGFR antibodies were used in this study. They both showed good biocompatibility. After irradiating ma€ lignant lung cancer cells A549 with NIR laser (800 nm), cell viability reduced dramatically in cultures treated by anti-EGFR conjugated with $\mathrm{Au}_{0.3} \mathrm{Ag}_{0.7}$ dendrites, while the laser power was in the range of $10-15 \mathrm{~W} \mathrm{~cm}^{-2} .^{72}$ Other similar studies have been summarized in Table 4 .

\section{Discussion}

The combination of nanoparticles and laser therapy elim- 







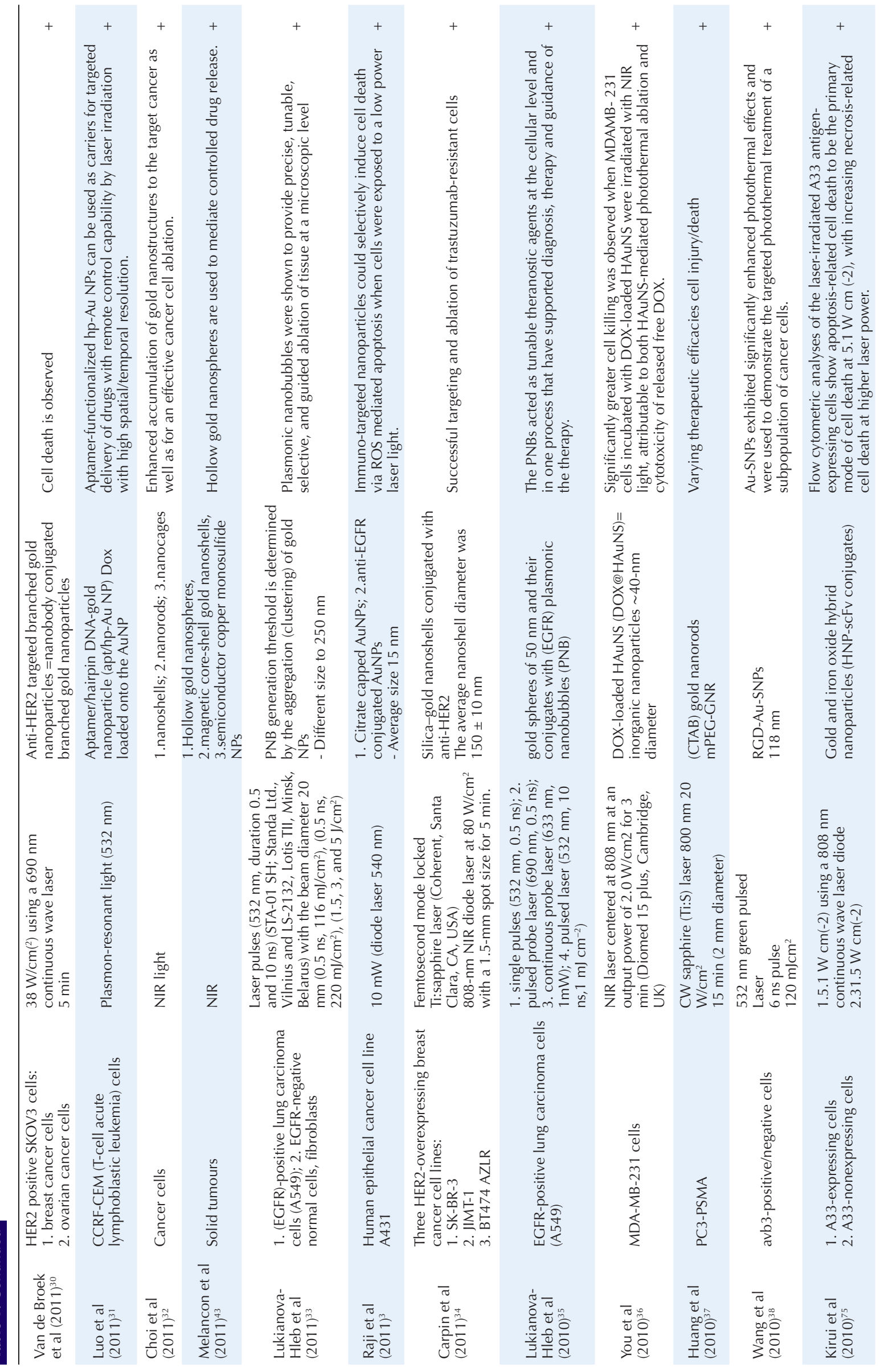









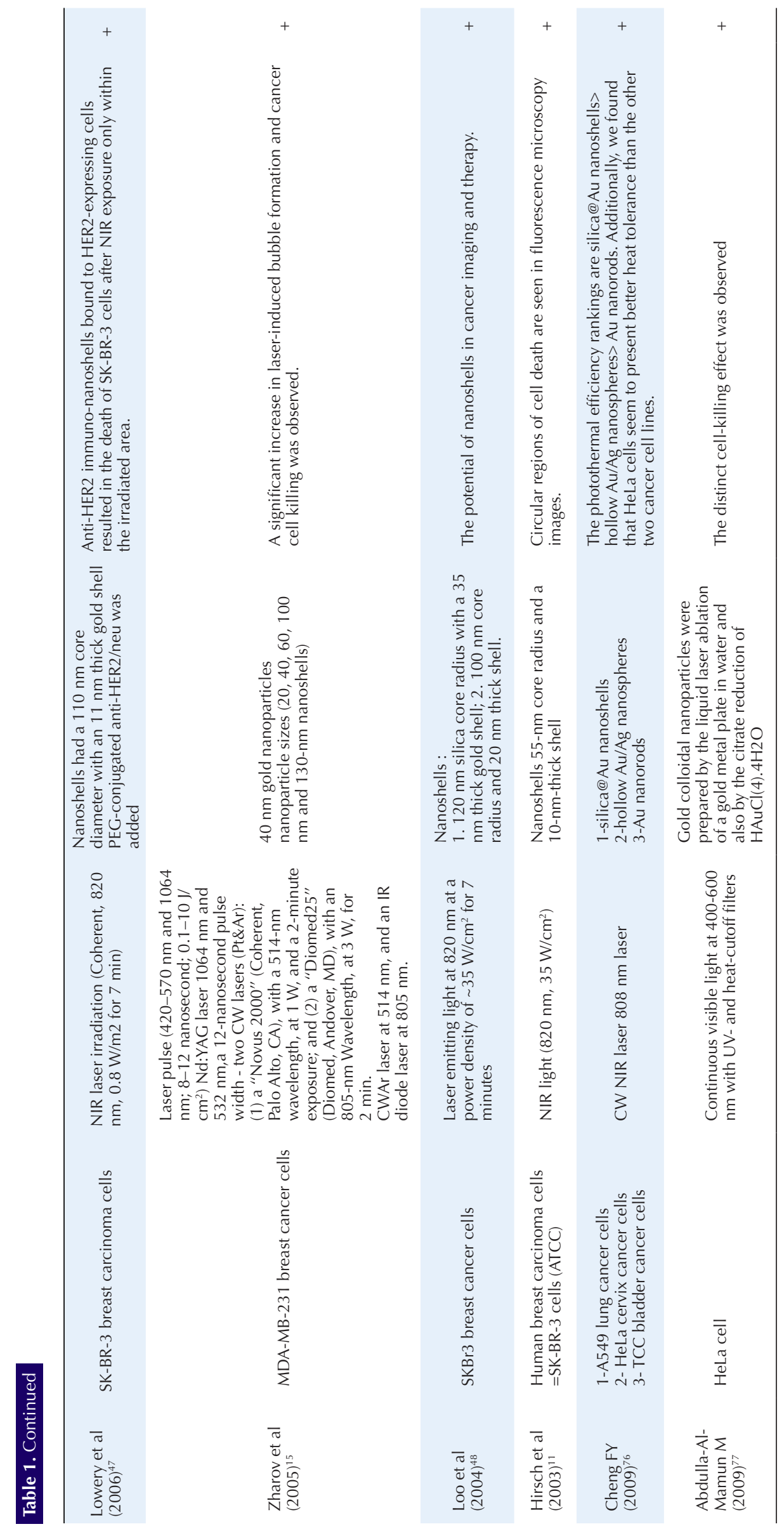




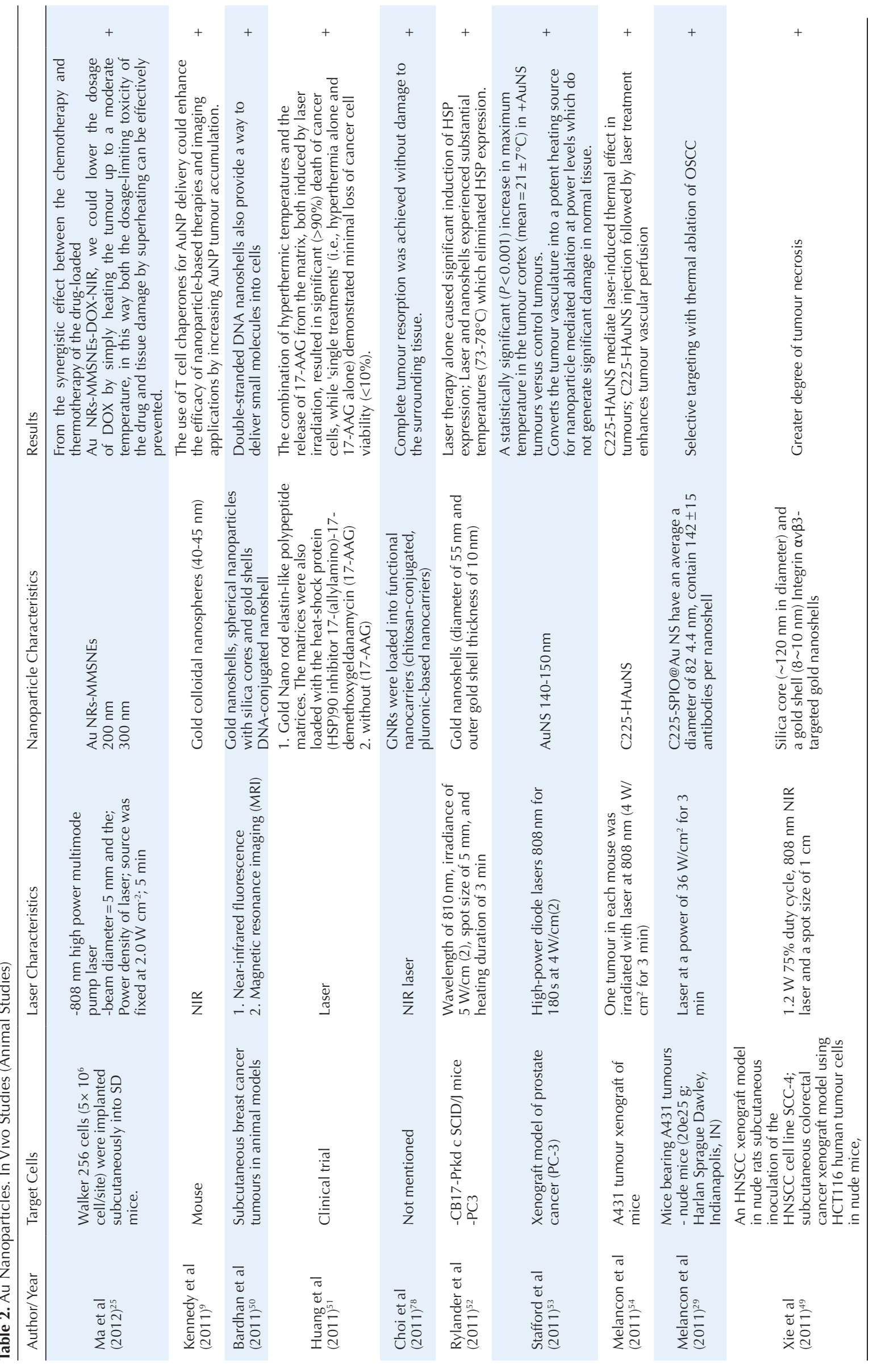






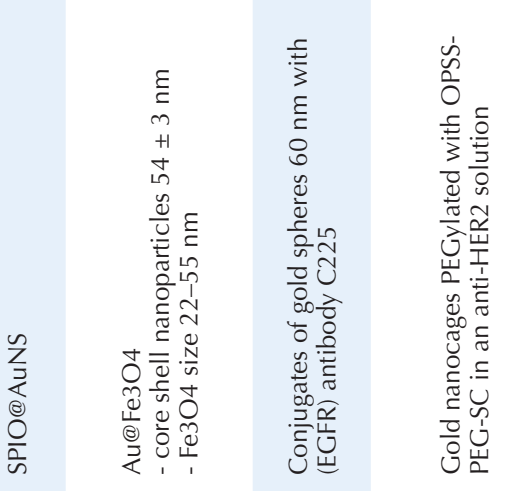
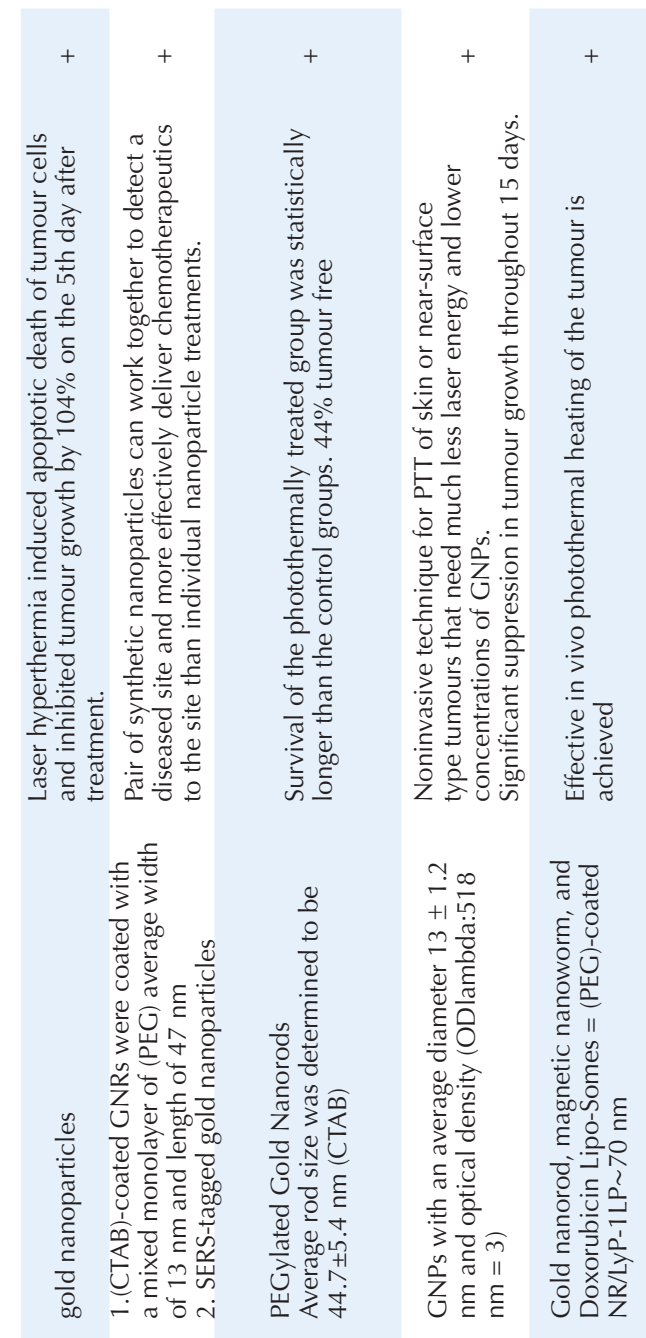

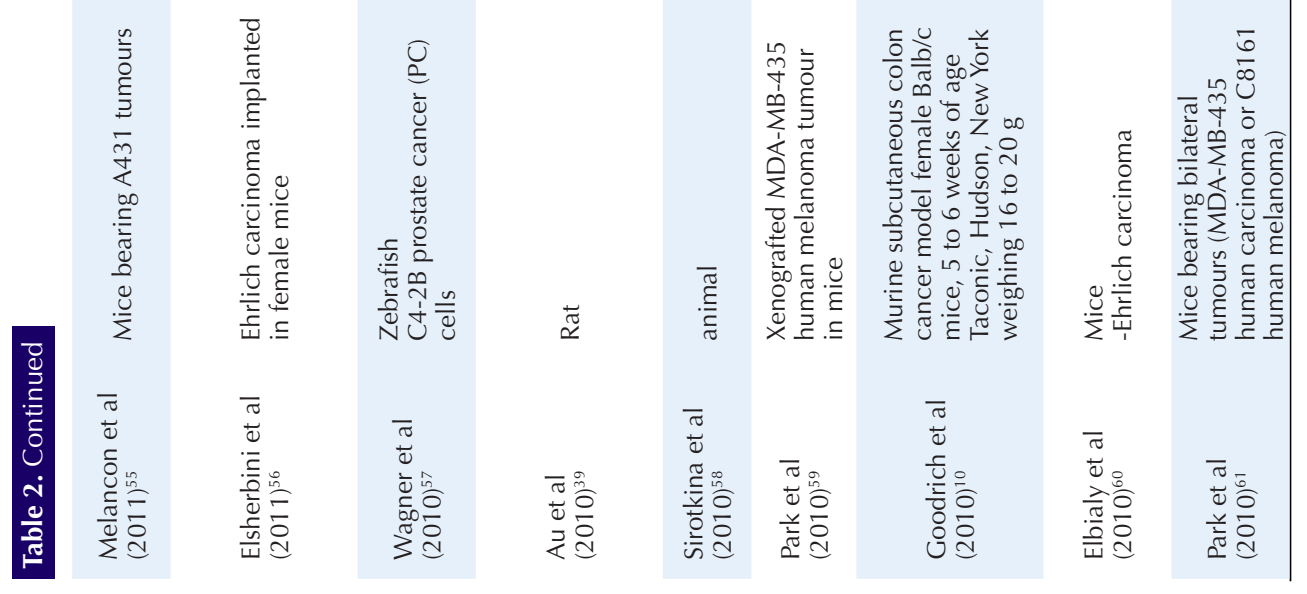







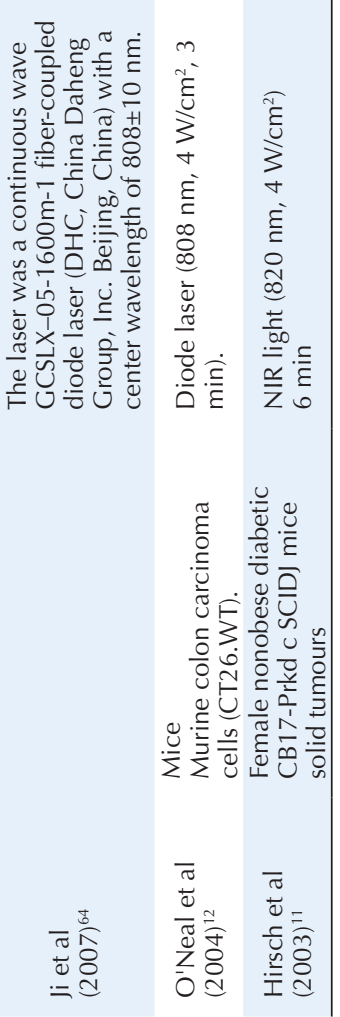

inates cancer cells via two mechanisms. First, there are a series of specific molecules such as HER2, ERBB1 on the surface of cancer cells. Initially, antibodies against these molecules are designed, and then nanoparticles are bind to these antibodies. These nanoparticles attached to the antibody and then to the cell surface molecules. The tumour area is irradiated with a laser, which has most absorption in nanoparticles. Laser irradiation causes heat in the gold or silver area and the total heat leads to the selective death of cancer cells. Such mechanism, which can target cancer cells selectively, is not seen in other methods such as chemotherapy and surgery. In fact, this is the advantage of such mechanism..$^{22,37,39,65}$

In the second mechanism murine macrophage is used and it is labeled with cell fluorescent dye PKH26GLred. Then gold nanoshells are loaded to the macrophages under 710 to $820 \mathrm{~nm}$ light and the tumour/macrophage hybrid is produced by centrifusion. Afterwards, the hybrid is irradiated with $810 \mathrm{~nm}$ laser with the power density of 2- 28 $\mathrm{W} / \mathrm{cm}^{2}$. Laser light not only destroys the macrophages but is also toxic to the surrounding cells. ${ }^{27}$

A brief survey shows that no study has been done on humans and most of the studies have been done in vitro and some of them on animals. The reason might be limited volunteer patients, and the fact that this method is a complicated and novel science. Studies also showed that in treatment of cancer cells the most used nanoparticle are gold $(\mathrm{Au})$ and silver $(\mathrm{Ag})$ nanoparticles or to a lesser extent, a combination of gold and silver nanoparticles. Besides, the highest laser wavelength is in the visible and NIR range (400-1200 nm), so the outcome is related to the optical properties of the biological tissues.

In all in vitro and animal studies, the result of combined use of nanoparticle and laser for therapeutic purposes was the death of cancerous cells and enhancement of tumour contrast for imaging intentions. . $^{3,25,38,48}$

The type of Laser applied in most of the investigations was NIR with wavelength spectra of $785 \mathrm{~nm}$ up to 1046 $\mathrm{nm}, 4,7,10,15,21,39,40,56,59$ with $808 \mathrm{~nm}$ wavelength used more frequently. ${ }^{10,20,25,29,34,41,49,62,72}$ As mentioned earlier, the 808 $\mathrm{nm}$ wavelength was the most effective in studies aiming at photothermal destruction of cancer cells. The absorption peak of gold nanoparticles can be modulated by creating different shapes and size. ${ }^{73,74}$

Another investigated wavelength was in the visible light spectra: $420 \mathrm{~nm}$ up to $690 \mathrm{~nm} .^{3,15,21,33,35,38,46,56,70}$ The app plication of this wavelength was mostly in generating nanobubbles ${ }^{15,33,35,38,46}$ and destruction of cancer cells in nanocomposites system. ${ }^{21,56} \mathrm{Nd}$ :YAG, Diode laser and Ti:sapphire were such systems. Samples were chosen from epithelial carcinomas including: A431, ${ }^{3,54}$ lung carcinoma cells (A549), ${ }^{20,33,35,72}$ glioblastoma, ${ }^{7}$ SK-BR-3 $3^{4,34,39,40,48}$ and other carcinomas occurring in epithelial tissues. Nanoparticles included gold silica nanoshells, ${ }^{21,22,27,41,43,48,49}$ gold nanoparticles, ${ }^{15,20,46}$ triangular silver nanoparticles, hollow gold nanospheres, ${ }^{21,44,54,62}$ silver dendrimer nanocomposites, ${ }^{70}$ gold nanorods, ${ }^{10,20,21} \mathrm{Au}_{x} \mathrm{Ag}_{x}{ }^{72}$ gold nanocages ${ }^{39}$ and gold nanocomposites. ${ }^{25,29,38,40,56}$ 
Table 3. Ag Nanoparticles (In Vitro Studies)

\begin{tabular}{|c|c|c|c|c|c|}
\hline Author/Year & Target Cells & Laser Characteristics & Nanoparticle Characteristics & Results & \\
\hline $\begin{array}{l}\text { Huang et al } \\
(2011)^{69}\end{array}$ & $\begin{array}{l}\text { Liver cancer } \\
\text { cells }\end{array}$ & $\begin{array}{l}30 \mathrm{~min} \\
2 \mathrm{~W}, 808 \mathrm{~nm} \text { laser } \\
\text { power density of } 1.4 \\
\mathrm{~W} \mathrm{~cm}^{-2}\end{array}$ & $\begin{array}{l}\text { Mean diameter of } 83 \text { nm } \\
\text { silica-coated plasmonic Pd@ } \\
\text { Ag core-shell nanoplates } \\
\text { Plasmonic Pd@Ag Core-Shell } \\
\text { Bimetallic Nanoplates }\end{array}$ & $\begin{array}{l}\sim 100 \% \text { of the liver cancer } \\
\text { cells were killed after irradiation for } 5 \text { min with } \\
\text { an } 808 \mathrm{~nm} \\
\text { laser providing a power density of } 1.4 \mathrm{~W} \mathrm{~cm}^{-2}\end{array}$ & + \\
\hline $\begin{array}{l}\text { Boca et al } \\
(2011)^{65}\end{array}$ & $\begin{array}{l}\text { Human non- } \\
\text { small lung } \\
\text { cancer cells } \\
(\mathrm{NCl}-\mathrm{H} 460)\end{array}$ & $\begin{array}{l}800 \mathrm{~nm} \text { wavelength } \\
\text { Ti:sapphire laser }\end{array}$ & $\begin{array}{l}\text { Chitosan-coated silver } \\
\text { nanotriangles (Chit-AgNTs) }\end{array}$ & $\begin{array}{l}\text { Biocompatible plasmonic nanoparticles with } \\
\text { high potential to be implemented as effective } \\
\text { phototherapeutic agents in the battle against } \\
\text { cancer. }\end{array}$ & + \\
\hline $\begin{array}{l}\text { Tse et } \\
\mathrm{al}(2011)^{70}\end{array}$ & $\begin{array}{l}\text { KB tumour } \\
\text { cells human } \\
\text { epidermoid } \\
\text { cancer cell } \\
\text { line }\end{array}$ & $\begin{array}{l}\text { NIR femtosecond } \\
\text { Three different average } \\
\text { laser powers: } 1.2 \mathrm{~mW} \text {, } \\
0.6 \mathrm{~mW} \text {, and } 0.12 \mathrm{~mW} \text {. }\end{array}$ & $\begin{array}{l}\text { Silver-dendrimer composite } \\
\text { nanodevices (CNDs) CNDs } \\
{[(\mathrm{Ag}(0))(25)-\mathrm{PAMAM}} \\
\text { E5.(NH(2))(42)(NGly)(74)(NFA) } \\
(2.7)] \text { dendrimer-folic acid (FA) } \\
\text { conjugates }\end{array}$ & $\begin{array}{l}\text { Significant reduction in breakdown threshold } \\
\text { and thus selectively promoting intracellular laser- } \\
\text { induced optical breakdown. }\end{array}$ & + \\
\hline
\end{tabular}

Table 4. Combination of $\mathrm{Ag} \& \mathrm{Au}$ Nanoparticles (In Vitro Studies)

\begin{tabular}{|c|c|c|c|c|c|}
\hline Author/Year & Target Cells & Laser Characteristics & Nanoparticle Characteristics & Results & \\
\hline $\begin{array}{l}\text { Huang et al } \\
(2008)^{71}\end{array}$ & (NB-4) cells & $\begin{array}{l}8.5 \times 10(4) \mathrm{W} / \mathrm{m}(2) \\
\text { laser exposure }\end{array}$ & Au-Ag NRs & $\begin{array}{l}\text { Au-Ag nanorod combination offers } \\
\text { selective and efficient photothermal } \\
\text { killing of targeted tumour cells. } \\
\text { The tumour tissue will be selectively } \\
\text { destroyed at laser energies which will } \\
\text { not harm the surrounding normal tissue. }\end{array}$ & + \\
\hline $\begin{array}{l}\text { Hu et al } \\
(2008)^{72}\end{array}$ & $\begin{array}{l}\text { SK-BR-3 (Her2/neu- } \\
\text { positive breast cancer } \\
\text { cells) and H520 (Her2/ } \\
\text { neu-negative lung cancer } \\
\text { cells) cells }\end{array}$ & $\begin{array}{l}\text { NIR region } 800 \mathrm{~nm} \\
35 \mathrm{Wcm}^{2} \text { for } 7 \mathrm{~min} \\
\text { femtosecond pulse } \\
\text { laser Ti:sapphire }\end{array}$ & $\begin{array}{l}\text { Anti-EGFR-conjugated } \mathrm{Au}(\mathrm{x}) \\
\mathrm{Ag}(1-\mathrm{x}) \text { nanostructures with } \\
\text { dendrite morphology and } \\
\text { a hollow interior dendrites } \\
400 \mathrm{~nm}\end{array}$ & $\begin{array}{l}\text { The hollow } \mathrm{Au}_{0.3} \mathrm{Ag}_{0.7} \text { nano structured } \\
\text { dendrites show potential in photo } \\
\text { thermolysis for killing cancer cells. }\end{array}$ & \\
\hline
\end{tabular}

Antibodies anti-HER2, anti-EGFR were used the most to conjugate with nanoparticles and acts as nanocarriers. $3,34,35,39,40$

Some studies used macrophages as biocarriers of nanoparticles, through phagocytosis. ${ }^{7,27}$ The main tasks of macrophages are to overwhelm and digest alien material of the body, so they easily move due to their migration capability and can simply surround cancer tumours. Besides macrophages are exceedingly located inside and around cancer tumours, while some studies show that up to $30 \%$ of cancer tumours consist of macrophages. ${ }^{7,27}$ Most studies used gold as the only nanoagents. These nanoparticles powerfully absorb laser light, are nontoxic, easily conjugates with proteins and antibodies, and have tunable optical properties. ${ }^{3}$ Two studies focused their investigations only on silver nanoparticles ${ }^{65,70}$ that were also effective in cancer therapy, but no study compared gold only and silver only nanoparticles with each other. Two studies investigated the combination of gold and silver as a unit agent, ${ }^{71,72}$ which showed better performance than gold alone.

Disadvantages of lasers and nanoparticles combined therapy include high cost and difficulty finding identical particles. Besides, it requires complicated and advanced technology which may not be easily obtained.

\section{Conclusion}

It can be concluded that laser and nanoparticles together are a novel class of cancer therapy and diagnosis. More studies should be done to identify the most effective nanoparticles and laser wavelength. Also, more animal studies and clinical trials need to be done as mandated by the lack of valid enough studies in this field.

These methods and mechanisms can be used as a treatment modality to aid cure cancers in future.

\section{Conflict of Interest}

The authors declare that there is no conflict of interest regarding the publication of this paper.

\section{References}

1. Mitchell R, Kumar V, Fausto N, Abbas AK, Aster J. Robbins \& Cotran Pathologic Basis of Disease. Saunders; 2011:260262.

2. Roco MC. Nanotechnology: convergence with modern biology and medicine. Curr Opin Biotechnol. 2003;14(3):337-346.

3. Raji V, Kumar J, Rejiya CS, Vibin M, Shenoi VN, Abraham A. Selective photothermal efficiency of citrate capped gold nanoparticles for destruction of cancer cells. Exp Cell Res. 2011;317(14):2052-2058. doi:10.1016/j.yexcr.2011.04.010.

4. Sun X, Zhang G, Patel D, Stephens D, Gobin AM. Targeted cancer therapy by immunoconjugated gold-gold sulfide nanoparticles using Protein G as a cofactor. Ann Biomed Eng. 2012;40(10):2131-2139. doi:10.1007/s10439-0120575-7.

5. Lu BQ, Zhu YJ, Ao HY, Qi C, Chen F. Synthesis and characterization of magnetic iron oxide/calcium silicate mesoporous nanocomposites as a promising vehicle for drug delivery. ACS Appl Mater Interfaces. 2012;4(12):69696974. doi:10.1021/am3021284.

6. Geng J, Li M, Wu L, Chen C, Qu X. Mesoporous silica nanoparticle-based $\mathrm{H} 2 \mathrm{O} 2$ responsive controlled-release 
system used for Alzheimer's disease treatment. Adv Healthc Mater. 2012;1(3):332-336. doi:10.1002/adhm.201200067.

7. Madsen SJ, Baek SK, Makkouk AR, Krasieva T, Hirschberg H. Macrophages as cell-based delivery systems for nanoshells in photothermal therapy. Ann Biomed Eng. 2012;40(2):507-515. doi:10.1007/s10439-011-0415-1.

8. You J, Zhang R, Zhang G, et al. Photothermal-chemotherapy with doxorubicin-loaded hollow gold nanospheres: A platform for near-infrared light-trigged drug release. J Control Release. 2012;158(2):319-328. doi:10.1016/j. jconrel.2011.10.028

9. Kennedy LC, Bear AS, Young JK, et al. T cells enhance gold nanoparticle delivery to tumors in vivo. Nanoscale Res Lett. 2011;6(1):283. doi:10.1186/1556-276X-6-283

10. Goodrich GP, Bao L, Gill-Sharp K, Sang KL, Wang J, Payne JD. Photothermal therapy in a murine colon cancer model using near-infrared absorbing gold nanorods. J Biomed Opt. 2010;15(1):018001. doi:10.1117/1.3290817

11. Hirsch LR, Stafford RJ, Bankson JA, et al. Nanoshellmediated near-infrared thermal therapy of tumors under magnetic resonance guidance. Proc Natl Acad Sci U S A. 2003;100(23):13549-13554. doi:10.1073/pnas.2232479100.

12. O'Neal DP, Hirsch LR, Halas NJ, Payne JD, West JL. Photothermal tumor ablation in mice using near infraredabsorbing nanoparticles. Cancer Lett. 2004;209(2):171-176. doi:10.1016/j.canlet.2004.02.004

13. Zharov VP, Kim JW, Curiel DT, Everts M. Self-assembling nanoclusters in living systems: application for integrated photothermal nanodiagnostics and nanotherapy. Nanomedicine. 2005;1(4):326-345. doi:10.1016/j. nano.2005.10.006.

14. Huang X, El-Sayed IH, Qian W, El-Sayed MA. Cancer cell imaging and photothermal therapy in the nearinfrared region by using gold nanorods. J Am Chem Soc. 2006;128(6):2115-2120. doi:10.1021/ja057254a

15. Zharov VP, Galitovskaya EN, Johnson C, Kelly T. Synergistic enhancement of selective nanophotothermolysis with gold nanoclusters: potential for cancer therapy. Lasers Surg Med. 2005;37(3):219-226. doi:10.1002/lsm.20223

16. Khlebtsov B, Zharov V, Melnikov A, Tuchin V. Optical amplification of photothermal therapy with gold nanoparticles and nanoclusters. Nanotechnology. 2006; 17:5167-5179.

17. Zhang XD, Wu D, Shen X, Liu PX, Fan FY, Fan SJ. In vivo renal clearance, biodistribution, toxicity of gold nanoclusters. Biomaterials. 2012;33(18):4628-4638. doi:10.1016/j.biomaterials.2012.03.020.

18. Simpson CA, K JS, Cliffel DE, Feldheim DL. In vivo toxicity, biodistribution, and clearance of glutathionecoated gold nanoparticles. Nanomedicine. 2013;9(2):257263. doi:10.1016/j.nano.2012.06.002

19. Jenkins JT, Halaney DL, Sokolov KV, et al. Excretion and toxicity of gold-iron nanoparticles. Nanomedicine. 2013;9(3):356-365. doi:10.1016/j.nano.2012.08.007

20. Kuo WS, Chang YT, Cho KC, et al. Gold nanomaterials conjugated with indocyanine green for dualmodality photodynamic and photothermal therapy. Biomaterials. 2012;33(11):3270-3278. doi:10.1016/j. biomaterials.2012.01.035.

21. Kessentini S, Barchiesi D. Quantitative comparison of optimized nanorods, nanoshells and hollow nanospheres for photothermal therapy. Biomed Opt Express. 2012;3(3):590-604. doi:10.1364/BOE.3.000590

22. Fekrazad R, Hakimiha N, Farokhi E, et al. Treatment of oral squamous cell carcinoma using anti-HER2 immunonanoshells. Int J Nanomedicine. 2011;6:2749-2755. doi:10.2147/IJN.S24548

23. Day ES, Bickford LR, Slater JH, Riggall NS, Drezek RA, West JL. Antibody-conjugated gold-gold sulfide nanoparticles as multifunctional agents for imaging and therapy of breast cancer. Int J Nanomedicine. 2010;5:445-454.

24. Botella P, Ortega I, Quesada M, et al. Multifunctional hybrid materials for combined photo and chemotherapy of cancer. Dalton Trans. 2012;41(31):9286-9296. doi:10.1039/ c2dt30381g.

25. Ma M, Chen H, Chen $\mathrm{Y}$, et al. Au capped magnetic core/ mesoporous silica shell nanoparticles for combined photothermo-/chemo-therapy and multimodal imaging. Biomaterials. 2012;33(3):989-998. doi:10.1016/j. biomaterials.2011.10.017.

26. Qin G, Li Z, Xia R, et al. Partially polymerized liposomes: stable against leakage yet capable of instantaneous release for remote controlled drug delivery. Nanotechnology. 2011;22(15):155605. doi:10.1088/0957-4484/22/15/155605.

27. Baek SK, Makkouk AR, Krasieva T, Sun CH, Madsen SJ, Hirschberg H. Photothermal treatment of glioma; an in vitro study of macrophage-mediated delivery of gold nanoshells. J Neurooncol. 2011;104(2):439-448. doi:10.1007/s11060-010-0511-3.

28. Beqa L, Fan Z, Singh AK, Senapati D, Ray PC. Gold nano-popcorn attached SWCNT hybrid nanomaterial for targeted diagnosis and photothermal therapy of human breast cancer cells. ACS Appl Mater Interfaces. 2011;3(9):3316-3324. doi:10.1021/am2004366.

29. Melancon MP, Lu W, Zhong M, et al. Targeted multifunctional gold-based nanoshells for magnetic resonance-guided laser ablation of head and neck cancer. Biomaterials. 2011;32(30):7600-7608. doi:10.1016/j. biomaterials.2011.06.039.

30. Van de Broek B, Devoogdt N, D'Hollander A, et al. Specific cell targeting with nanobody conjugated branched gold nanoparticles for photothermal therapy. ACS Nano. 2011;5(6):4319-4328. doi:10.1021/nn1023363.

31. Luo YL, Shiao YS, Huang YF. Release of photoactivatable drugs from plasmonic nanoparticles for targeted cancer therapy. ACS Nano. 2011;5(10):7796-7804. doi:10.1021/ nn201592s.

32. Choi J, Yang J, Jang E, et al. Gold nanostructures as photothermal therapy agent for cancer. Anticancer Agents Med Chem. 2011;11(10):953-964.

33. Lukianova-Hleb EY, Koneva, II, Oginsky AO, La Francesca S, Lapotko DO. Selective and self-guided micro-ablation of tissue with plasmonic nanobubbles. J Surg Res. 2011;166(1):e3-13. doi:10.1016/j.jss.2010.10.039.

34. Carpin LB, Bickford LR, Agollah G, et al. Immunoconjugated gold nanoshell-mediated photothermal ablation of trastuzumab-resistant breast cancer cells. Breast Cancer Res Treat. 2011;125(1):27-34. doi:10.1007/s10549-010-0811-5.

35. Lukianova-Hleb EY, Hanna EY, Hafner JH, Lapotko DO. Tunable plasmonic nanobubbles for cell theranostics. Nanotechnology. 2010;21(8):85102. doi:10.1088/09574484/21/8/085102.

36. You J, Zhang G, Li C. Exceptionally high payload of doxorubicin in hollow gold nanospheres for near-infrared light-triggered drug release. ACS Nano. 2010;4(2):1033-41. doi:10.1021/nn901181c.

37. Huang HC, Rege K, Heys JJ. Spatiotemporal temperature distribution and cancer cell death in response to 
extracellular hyperthermia induced by gold nanorods. ACS Nano. 2010;4(5):2892-2900. doi:10.1021/nn901884d.

38. Wang S, Chen KJ, Wu TH, et al. Photothermal effects of supramolecularly assembled gold nanoparticles for the targeted treatment of cancer cells. Angew Chem Int Ed Engl. 2010;49(22):3777-3781. doi:10.1002/anie.201000062

39. Au L, Chen J, Wang LV, Xia Y. Gold nanocages for cancer imaging and therapy. Methods Mol Biol. 2010;624:83-99. doi:10.1007/978-1-60761-609-2_6.

40. Wang C, Chen J, Talavage T, Irudayaraj J. Gold nanorod/Fe3O4 nanoparticle "nano-pearl-necklaces" for simultaneous targeting, dual-mode imaging, and photothermal ablation of cancer cells. Angew Chem Int Ed Engl. 2009;48(15):2759-2763. doi:10.1002/anie.200805282.

41. Melancon MP, Lu W, Yang Z, et al. In vitro and in vivo targeting of hollow gold nanoshells directed at epidermal growth factor receptor for photothermal ablation therapy. Mol Cancer Ther. 2008;7(6):1730-1739. doi:10.1158/15357163.MCT-08-0016.

42. Liu X, Lloyd MC, Fedorenko IV, Bapat P, Zhukov T, Huo Q. Enhanced imaging and accelerated photothermalysis of A549 human lung cancer cells by gold nanospheres. Nanomedicine (Lond). 2008;3(5):617-626. doi:10.2217/17435889.3.5.617.

43. Bernardi RJ, Lowery AR, Thompson PA, Blaney SM, West JL. Immunonanoshells for targeted photothermal ablation in medulloblastoma and glioma: an in vitro evaluation using human cell lines. J Neurooncol. 2008;86(2):165-172. doi:10.1007/s11060-007-9467-3.

44. Huang X, Qian W, El-Sayed IH, El-Sayed MA. The potential use of the enhanced nonlinear properties of gold nanospheres in photothermal cancer therapy. Lasers Surg Med. 2007;39(9):747-753. doi:10.1002/lsm.20577.

45. Stern JM, Stanfield J, Lotan Y, Park S, Hsieh JT, Cadeddu JA. Efficacy of laser-activated gold nanoshells in ablating prostate cancer cells in vitro. J Endourol. 2007;21(8):939943. doi:10.1089/end.2007.0437.

46. El-Sayed IH, Huang X, El-Sayed MA. Selective laser photothermal therapy of epithelial carcinoma using anti-EGFR antibody conjugated gold nanoparticles. Cancer Lett. 2006;239(1):129-135. doi:10.1016/j.canlet.2005.07.035.

47. Lowery AR, Gobin AM, Day ES, Halas NJ, West JL. Immunonanoshells for targeted photothermal ablation of tumor cells. Int J Nanomedicine. 2006;1(2):149-154.

48. Loo C, Lin A, Hirsch L, et al. Nanoshell-enabled photonicsbased imaging and therapy of cancer. Technol Cancer Res Treat. 2004;3(1):33-40.

49. Xie H, Diagaradjane P, Deorukhkar AA, et al. Integrin alphavbeta3-targeted gold nanoshells augment tumor vasculature-specific imaging and therapy. Int $J$ Nanomedicine. 2011;6:259-269. doi:10.2147/IJN.S15479.

50. Bardhan R, Lal S, Joshi A, Halas NJ. Theranostic nanoshells: from probe design to imaging and treatment of cancer. Acc Chem Res. 2011;44(10):936-946. doi:10.1021/ar200023x.

51. Huang HC, Yang Y, Nanda A, Koria P, Rege K. Synergistic administration of photothermal therapy and chemotherapy to cancer cells using polypeptide-based degradable plasmonic matrices. Nanomedicine (Lond). 2011;6(3):459473. doi:10.2217/nnm.10.133.

52. Rylander MN, Stafford RJ, Hazle J, Whitney J, Diller KR. Heat shock protein expression and temperature distribution in prostate tumours treated with laser irradiation and nanoshells. Int J Hyperthermia. 2011;27(8):791-801. doi:1 $0.3109 / 02656736.2011 .607485$.
53. Stafford RJ, Shetty A, Elliott AM, Schwartz JA, Goodrich GP, Hazle JD. MR temperature imaging of nanoshell mediated laser ablation. Int J Hyperthermia. 2011;27(8):782-790. doi: 10.3109/02656736.2011.614671.

54. Melancon MP, Elliott AM, Shetty A, Huang Q, Stafford RJ, Li C. Near-infrared light modulated photothermal effect increases vascular perfusion and enhances polymeric drug delivery. J Control Release. 2011;156(2):265-272. doi:10.1016/j.jconrel.2011.06.030.

55. Melancon MP, Elliott A, Ji X, et al. Theranostics with multifunctional magnetic gold nanoshells: photothermal therapy and $\mathrm{t} 2 *$ magnetic resonance imaging. Invest Radiol. 2011;46(2):132-140. doi:10.1097/RLI.0b013e3181f8e7d8.

56. Elsherbini AA, Saber M, Aggag M, El-Shahawy A, Shokier HA. Laser and radiofrequency-induced hyperthermia treatment via gold-coated magnetic nanocomposites. Int J Nanomedicine. 2011;6:2155-2165. doi:10.2147/IJN.S23952.

57. Wagner DS, Delk NA, Lukianova-Hleb EY, Hafner JH, Farach-Carson MC, Lapotko DO. The in vivo performance of plasmonic nanobubbles as cell theranostic agents in zebrafish hosting prostate cancer xenografts. Biomaterials. 2010;31(29):7567-7574. doi:10.1016/j. biomaterials.2010.06.031.

58. Sirotkina MA, Elagin VV, Shirmanova MV, et al. OCTguided laser hyperthermia with passively tumor-targeted gold nanoparticles. J Biophotonics. 2010;3(10-11):718-727. doi:10.1002/jbio.201000061.

59. Park JH, von Maltzahn G, Ong LL, et al. Cooperative nanoparticles for tumor detection and photothermally triggered drug delivery. Adv Mater. 2010;22(8):880-885. doi:10.1002/adma.200902895.

60. Elbialy N, Abdelhamid M, Youssef T. Low power argon laser-induced thermal therapy for subcutaneous Ehrlich carcinoma in mice using spherical gold nanoparticles. $J$ Biomed Nanotechnol. 2010;6(6):687-693.

61. Park JH, von Maltzahn G, Xu MJ, et al. Cooperative nanomaterial system to sensitize, target, and treat tumors. Proc Natl Acad Sci U S A. 2010;107(3):981-986. doi:10.1073/ pnas.0909565107.

62. Lu W, Xiong C, Zhang G, et al. Targeted photothermal ablation of murine melanomas with melanocytestimulating hormone analog-conjugated hollow gold nanospheres. Clin Cancer Res. 2009;15(3):876-886. doi:10.1158/1078-0432.CCR-08-1480.

63. Stern JM, Stanfield J, Kabbani W, Hsieh JT, Cadeddu JA. Selective prostate cancer thermal ablation with laser activated gold nanoshells. J Urol. 2008;179(2):748-753. doi:10.1016/j.juro.2007.09.018.

64. Ji X, Shao R, Elliott AM, et al. Bifunctional Gold Nanoshells with a Superparamagnetic Iron Oxide-Silica Core Suitable for Both MR Imaging and Photothermal Therapy. J Phys Chem C Nanomater Interfaces. 2007;111(17):6245. doi:10.1021/jp0702245.

65. Boca SC, Potara M, Gabudean AM, Juhem A, Baldeck PL, Astilean S. Chitosan-coated triangular silver nanoparticles as a novel class of biocompatible, highly effective photothermal transducers for in vitro cancer cell therapy. Cancer Lett. 2011;311(2):131-140. doi:10.1016/j. canlet.2011.06.022.

66. Kim JS, Kuk E, Yu KN, et al. Antimicrobial effects of silver nanoparticles. Nanomedicine. 2007;3(1):95-101. doi:10.1016/j.nano.2006.12.001

67. Sur I, Cam D, Kahraman M, Baysal A, Culha M. Interaction of multi-functional silver nanoparticles with living cells. 
Nanotechnology. 2010;21(17):175104. doi:10.1088/0957$4484 / 21 / 17 / 175104$.

68. Liu L, Ni F, Zhang J, et al. Silver nanocrystals sensitize magnetic-nanoparticle-mediated thermo-induced killing of cancer cells. Acta Biochim Biophys Sin (Shanghai). 2011;43(4):316-323. doi:10.1093/abbs/gmr015.

69. Huang X, Tang S, Liu B, Ren B, Zheng N. Enhancing the photothermal stability of plasmonic metal nanoplates by a core-shell architecture. Adv Mater. 2011;23(30):3420-3425. doi:10.1002/adma.201100905.

70. Tse C, Zohdy MJ, Ye JY, O’Donnell M, Lesniak W, Balogh L. Enhanced optical breakdown in KB cells labeled with folate-targeted silver-dendrimer composite nanodevices. Nanomedicine. 2011;7(1):97-106. doi:10.1016/j. nano.2010.09.003.

71. Huang YF, Sefah K, Bamrungsap S, Chang HT, Tan W. Selective photothermal therapy for mixed cancer cells using aptamer-conjugated nanorods. Langmuir. 2008;24(20):11860-11865. doi:10.1021/la801969c.

72. Hu KW, Huang CC, Hwu JR, Su WC, Shieh DB, Yeh CS. A New Photothermal Therapeutic Agent: Core-Free Nanostructured AuxAg1-x Dendrites. Chem. Eur. J. 2008;14:2956-2964.
73. Fulvio Ratto, Paolo Matteini, Francesca Rossi, Pini R. Size and shape control in the overgrowth of gold nanorods. $J$ Nanopart Res. 2010;12:2029-2036.

74. Matteini P, Ratto F, Rossi F, Pini R. Emerging concepts of laser-activated nanoparticles for tissue bonding. J Biomed Opt. 2012;17(1):010701. doi:10.1117/1.JBO.17.1.010701.

75. Kirui DK, Rey DA, Batt CA. Gold hybrid nanoparticles for targeted phototherapy and cancer imaging. Nanotechnology. 2010;21(10):105105.

76. Cheng FY, Chen CT, Yeh CS. Comparative efficiencies of photothermal destruction of malignant cells using antibody-coated silica@Au nanoshells, hollow Au/ $\mathrm{Ag}$ nanospheres and $\mathrm{Au}$ nanorods. Nanotechnology. 2009;20(42):425104.

77. Abdulla-Al-Mamun M, Kusumoto Y, Mihata A, Islam MS, Ahmmad B. Plasmon-induced photothermal cellkilling effect of gold colloidal nanoparticles on epithelial carcinoma cells. Photochem Photobiol Sci. 2009;8(8):11251129.

78. Choi WI, Kim JY, Kang C, Byeon CC, Kim YH, Tae G. Tumor regression in vivo by photothermal therapy based on gold-nanorod-loaded, functional nanocarriers. ACS Nano. 2011;5(3):1995-2003. 